\title{
Importance of old rural areas of Lubuskie Lakeland and central Pomerania for maintenance of vegetation diversity
}

\author{
Maria Wojterska*, Andrzej Brzeg \& Katarzyna Jasińska
}

Department of Plant Ecology and Environmental Protection, Faculty of Biology, Adam Mickiewicz University, Umultowska 89, 61-614 Poznań, Poland

* corresponding author (e-mail: mwzerios@amu.edu.pl)

\begin{abstract}
The study areas, located in northern and western Poland, comprised 30 villages of the Lubuskie Lakeland region and 18 in central Pomerania. A total number of recorded associations and local communities of similar rank was counted as 243 . In the list prevailed natural and seminatural communities. The endangered associations composed about $47.3 \%$ of the whole list of communities. Altogether, 8 communities, assessed as directly endangered, occurred in the villages or their vicinity. Comparison of plant communities of both regions revealed that the structure of vegetation shows many affinities, while the differences are more of qualitative than quantitative character. The diversity of vegetation of rural landscapes was slightly higher in the central Pomerania. The rural landscape of Lubuskie Lakeland was more transformed, richer in ruderal communities, whereas in Pomerania more represented were natural and seminatural communities. The rural landscape of both studied areas is still rich and diversified but recently undergoes transformations leading to its impoverishment and unification as a result of either abandonment of land use or its intensification and new forms of human impact.
\end{abstract}

Key words: villages of medieval origin, spatial-functional complexes, diversity of vegetation, threatened plant communities, Poland

\section{Introduction}

The composition of vegetation of rural areas, which constitute over 52\% of the area of Poland (GUS 2016), has to date been elaborated almost exclusively with regard to synanthropic plant communities, mostly segetal, however, without indication of relations with settlements (e.g., Kornaś 1968a; Siciński 1974; Warcholińska 1987; Anioł-Kwiatkowska 1990; Jackowiak et al. 1990; Wójcik 1998). The attention paid to the ruderal communities concentrated on towns (e.g. Fijałkowski 1963, 1967; Rostański \& Gutte 1971; Sowa 1971; Anioł-Kwiatkowska 1974; Zając 1974; Kępczyński 1975; Borysiak et al. 2000), whereas those occurring in villages were studied much more rarely (Pawlak 1981). The data on differentiation, frequency, distribution, threat and importance of this type of vegetation in the rural landscape are scattered in publications covering broader issues, especially syntaxonomic monographs (e.g., Faliński 1963, 1966; Fijałkowski 1978; Herbich 1982; Pender 1990; Siciński 1994;
Brzeg 2009; Szrama \& Brzeg 2011), or totally missing in many regions. The attempts toward comprehensive characteristics of vegetation of rural landscape taking into account also natural and seminatural vegetation were scanty (Balcerkiewicz et al. 1996; Wojterska 2003).

The documentation concerning synanthropic vegetation of both studied areas is scattered and varies depending on the vegetation type. The segetal communities belong to those which were fairly well documented (Libbert 1932; Passarge 1963; Nowiński 1964, 1965; Borowiec et al. 1974, 1977; Balcerkiewicz \& Pawlak 1978, 1990; Pawlak 1980, 1981; Herbich 1982; Kutyna 1988; Brzeg 1991; Sobisz 1996, 2006, 2007, 2012; Ratuszniak \& Sobisz 1999, 2000, 2001, $2004,2005)$. The same applies to some chosen ruderal communities (Libbert 1932; Ćwikliński 1974; Misiewicz 1976; Kępczyńska-Rijken 1977; Kępczyński \& Marszałkiewicz 1977; Pawlak 1980, 1981; Herbich 1982; Brzeg \& Rosadziński 2006, 2013; Brzeg et al. 2014a), but for the majority, the documentation is very 
poor, especially from rural areas; some syntaxa were not documented at all.

Published phytosociological documentation on other types of communities observed in our study in the rural landscape (e.g.: meadows and pastures, swards, forests, thickets and tall forbs) is also diversified but limited to their classical habitats in more natural or seminatural landscapes and does not pertain to the surroundings of villages.

The overview of aforementioned literature indicates that rural settlements and their surroundings were so far not studied in a comprehensive way. Therefore our investigations concentrated on the total diversity of plant cover in and around villages. For our studies, we have chosen villages of medieval origin, i.e., with equally long history of land use. The results of these investigations in floristic aspect were partly published (Brzeg et al. 2013, 2014b; Jasińska et al. 2015), whereas the aim of this paper was to present differentiation of all plant communities occurring in and in the direct neighbourhood of human settlements.

The detailed aims of this paper were to: $(i)$ recognize the contemporary vegetation of rural areas, the history of which goes back to medieval times, with regard to the origin, frequency and the degree of threat to plant communities, taking into account the problem of conservation of plant cover diversity and recent important transformations of the rural landscape in NW Poland, (ii) compare two areas: central Pomerania and the Lubuskie Lakeland, in the above context, as well as (iii) indicate the importance of rural landscapes for the maintenance of vegetation diversity through demonstration that they are also the place of occurrence of rare and endangered natural and seminatural plant communities.

\section{Material and methods}

The investigations were conducted in the years 2011-2014. The study material was collected in 30 villages of the Lubuskie Lakeland (LL) region and in 18 of central Pomerania (CP) (Fig. 1, Appendix 1). Both areas were chosen due to the fact, that their history and structure of settlements were earlier thoroughly studied (Rączkowski 1995, 2002; Wojterska et. al. 2007).

The investigated villages were exclusively of medieval origin with preserved traditional structure of linear, oval or round shape (Burszta 1958; Szulc 1995). The study comprised villages and their surrounding fields within a buffer zone of $200 \mathrm{~m}$, drawn in GIS program around the historic core area of a built-up part (Fig. 2).

Materials used in this study were collected within the following spatial-functional complexes (compare Jasińska et al. 2015): central green (CG), water bodies (P), built-up areas (BA; divided into BA1 - traditional, BA2 - manor, BA3 - blocks of flats), adjoining small

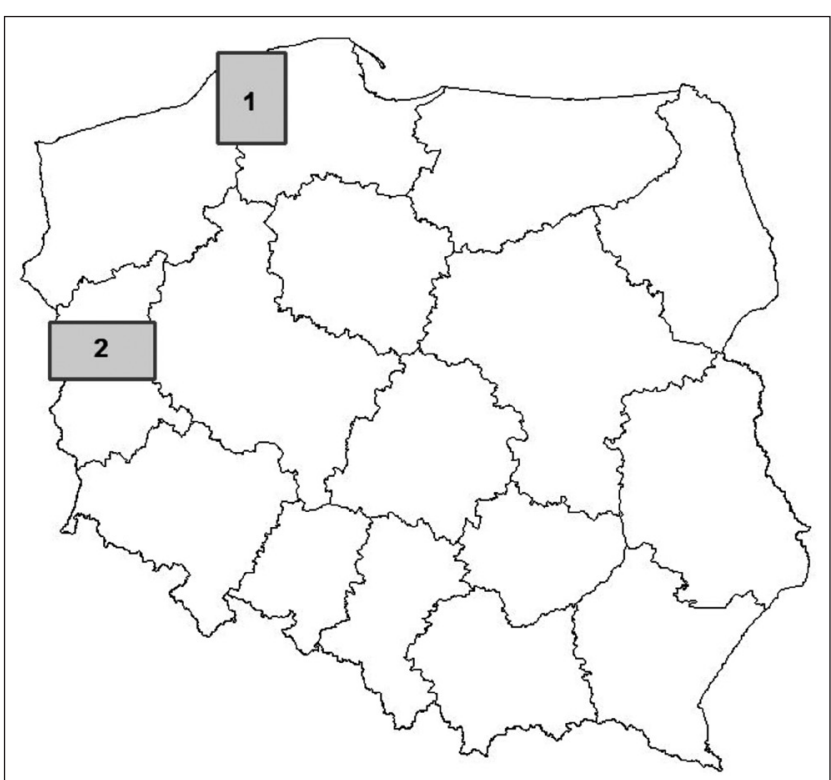

Fig. 1. Location of two studied areas: central Pomerania (1) and Lubuskie Lakeland (2)

fields (F1) and fields of different size beyond the surrounding road (F2), forest fragments (Fr), meadows and pastures $(\mathrm{M})$, cemeteries $(\mathrm{Cm})$, gravel pits $(\mathrm{GP})$, parks $(\mathrm{Pk})$ and railway (R). An example of spatial structure of one of the studied villages was shown in Fig. 2. Full material comprised complete lists of all communities observed in 361 spatial-functional complexes (224 from the Lubuskie Lakeland and 137 from Pomerania) and was further referred to as total. The single notice corresponds with the occurrence of community in one complex. The number of communities in one spatial complex varied from 1 (extremely poor $\mathrm{P}$ - water bodies complex) to 48 (especially rich small fields complex F1 adjoining the built up area), on average -16 . The differentiation of vegetation within these complexes will be the subject of separate publication.

For comparison of two regions, the data from 18 villages in Pomerania and from randomly selected 18 out 30 villages investigated in the Lubuskie Lakeland were taken into account (Appendix 1).

A full list of plant communities and their frequency in both compared areas (36 villages) was compiled in Appendix 1, with additional information concerning the syngenesis, as well as assessment of both the degree of threat and rarity in Poland. Syngenesis of syntaxa was assessed according to the concept of Faliński (1969), in which communities were divided into two main groups: a) autogenic communities - species compositions originating from primaeval nature without any human participation, composed of native species. This group was represented in our list by natural communities, i.e., such that (contrarily to primaeval communities) bear traces of human influence: 


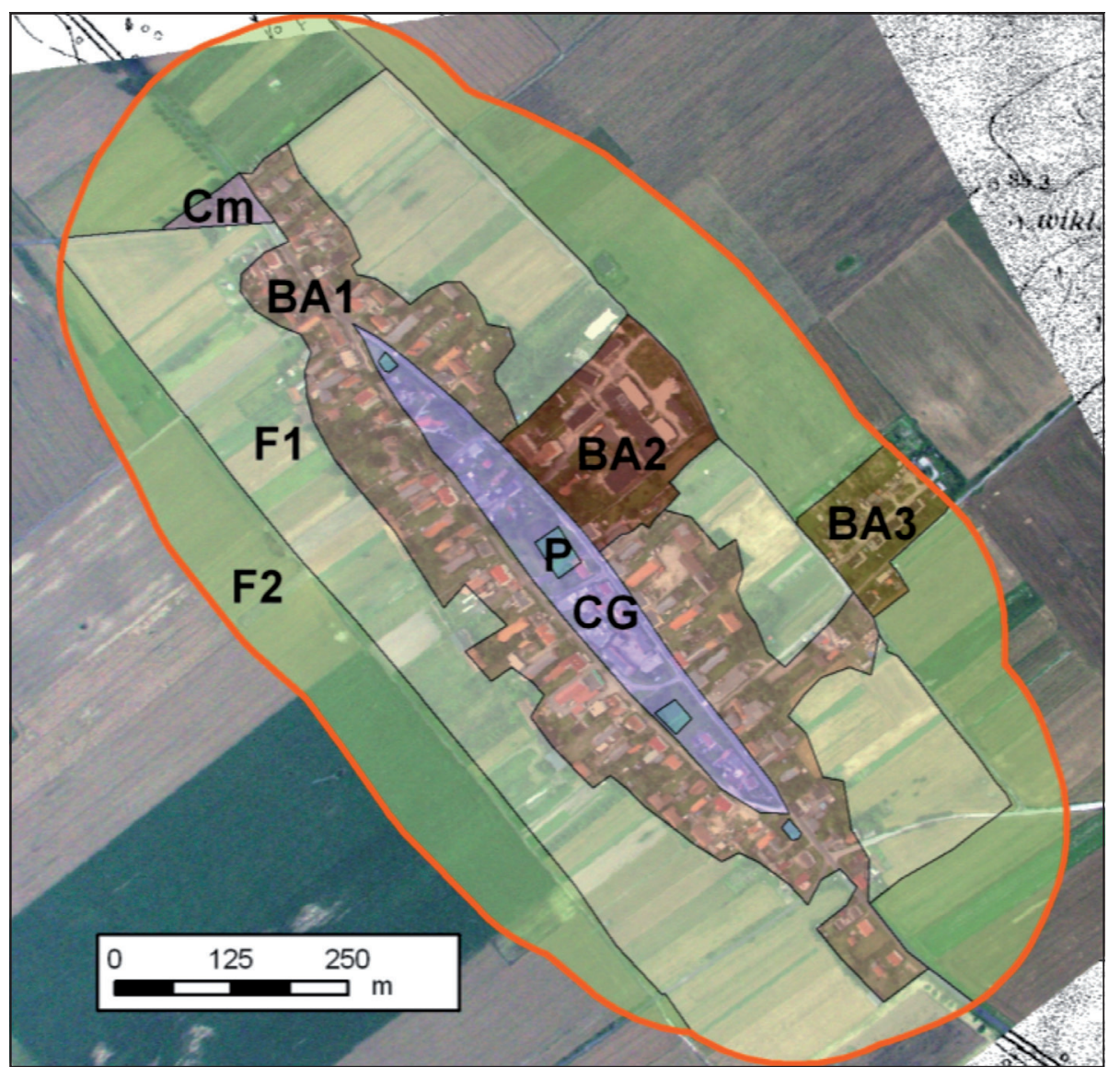

Fig. 2. Chociszewo in the Lubuskie Lakeland as an example of differentiation of spatial-functional complexes within a village and its surroundings

Explanations: BA - built-up areas (BA1 - traditional, BA2 - manor, BA3 - blocks of flats), CG - central green, Cm - cemetery, F1 - adjoining small fields, F2 - fields of different size beyond the surrounding road, P - water bodies; red line indicates the outer margin of investigated area including the $200 \mathrm{~m}$ broad buffer zone

- natural perdochoric; retreating under human impact (NP),

- natural stable $(\mathrm{N})$,

- natural auxochoric; with increasing number of phytocoenoses, expanding their range under human impact (NA),

b) anthropogenic communities - species compositions originating in historic times under human influence, with different participation of alien species:

- seminatural; composed of native species, developed in slightly transformed habitats under the influence of repeated human activities, e.g., mowing, grazing, trampling etc. (SN),

- synanthropic not specialised; old communities connected with cultural landscape, composed of native species and archaeophytes, occurring on transformed sites from which the natural vegetation was removed; divided into two units:

- synanthropic segetal occurring in cultivated fields (SS),

- synanthropic ruderal occurring within human settlements, along roads etc. (SR),
- synanthropic specialised; occurring in strongly transformed habitats or in habitats newly created by man and not present in nature, with significant role of kenophytes - epecophytes in the species composition; represented by:

- synanthropic ruderal specialised (SRS);

- xenospontaneous; composed of kenophytes - agriophytes, invading natural environments and outcompeting autogenic communities (X).

The main groups in the geographic-historical classification of the flora were adopted after Kornaś (1968b) and Tokarska-Guzik et al. (2011).

The syntaxonomic approach, nomenclature of communities and above mentioned additional data were taken from the work of Ratyńska et al. (2010). For the calculations and comparisons, conducted in Excel program, only relatively well developed phytocoenoses, i.e. undoubtedly recognizable after their species composition as already described units, were chosen. Fragmentarily developed and strongly impoverished communities (which could be ascribed 
only to phytosociological units of higher rank) were omitted.

\section{Results}

A total number of recorded associations and communities of analogous rank in the studied villages was 243 (Appendix 1). They belonged to 28 classes, 35 orders and 64 alliances within the phytosociological classification. The majority of them (162) were common for rural areas of both studied regions. In the compared 18 villages from each region, 194 associations or communities were found in central Pomerania, whereas in the Lubuskie Lakeland - 180.

In all studied sets, the most numerous was a group of natural auxochoric communities, followed by synanthropic ruderal group (Fig. 3). All remaining groups classified according to their syngenesis were less numerous. Worth mentioning was, on one hand, the higher share of natural perdochoric and xenospontaneous communities in Pomerania and, on the other, ruderal communities, especially ruderal specialized - in the Lubuskie Lakeland.
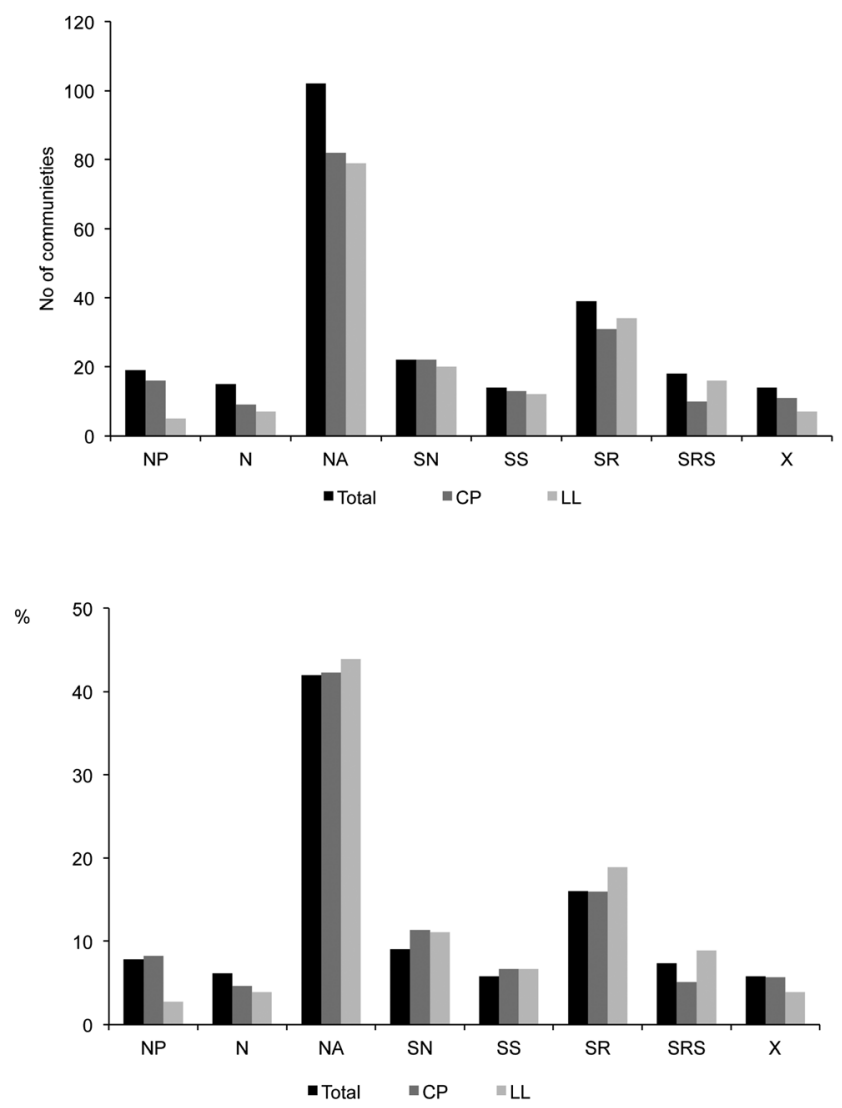

Fig. 3. The number and share of communities representing different categories of origin in central Pomerania (CP) and Lubuskie Lakeland (LL)

Explanations: $\mathrm{N}$ - natural, stable; $\mathrm{NP}$ - natural perdochoric; NA - natural auxochoric; $\mathrm{SN}$ - seminatural; SS - synanthropic segetal; SR - synanthropic ruderal; SSR - specialised synanthropic ruderal; $\mathrm{X}$ - xenospontaneous
The threatened associations composed about $47 \%$ of the whole list of communities (Fig. 4). The category E (directly endangered) was represented by 8 communities of different origin. Besides natural communities (partly auxochoric): Adoxo-Aceretum pseudoplatani, Asplenietum trichomano-rutae-murariae, Cystopteridetum fragilis, Fragario-Campanuletum cervicariae and Gymnocarpietum robertiani, there were also synanthropic ruderal, such as: Matricario-Anthemidetum cotulae, Poo-Coronopodetum squamati and Urtico urentis-Chenopodietum boni-henrici.

The general share of communities representing above mentioned category of threat is low and slightly higher in the Lubuskie Lakeland. The vulnerable (V) constituted $25 \%$ of the total list of communities, with an important role of a group of natural communities (45 syntaxa), and some contribution of seminatural (7), synanthropic segetal (6) and synanthropic ruderal (3). The most numerous in the first group were natural auxochoric (22), such as quite frequent: Scirpetum sylvatici (28 notices), Salicetum capreae (28) and FilipeduloGeranietum palustris (20), as well as those noted less than 10 times, e.g.: Airo caryophylleae-Festucetum
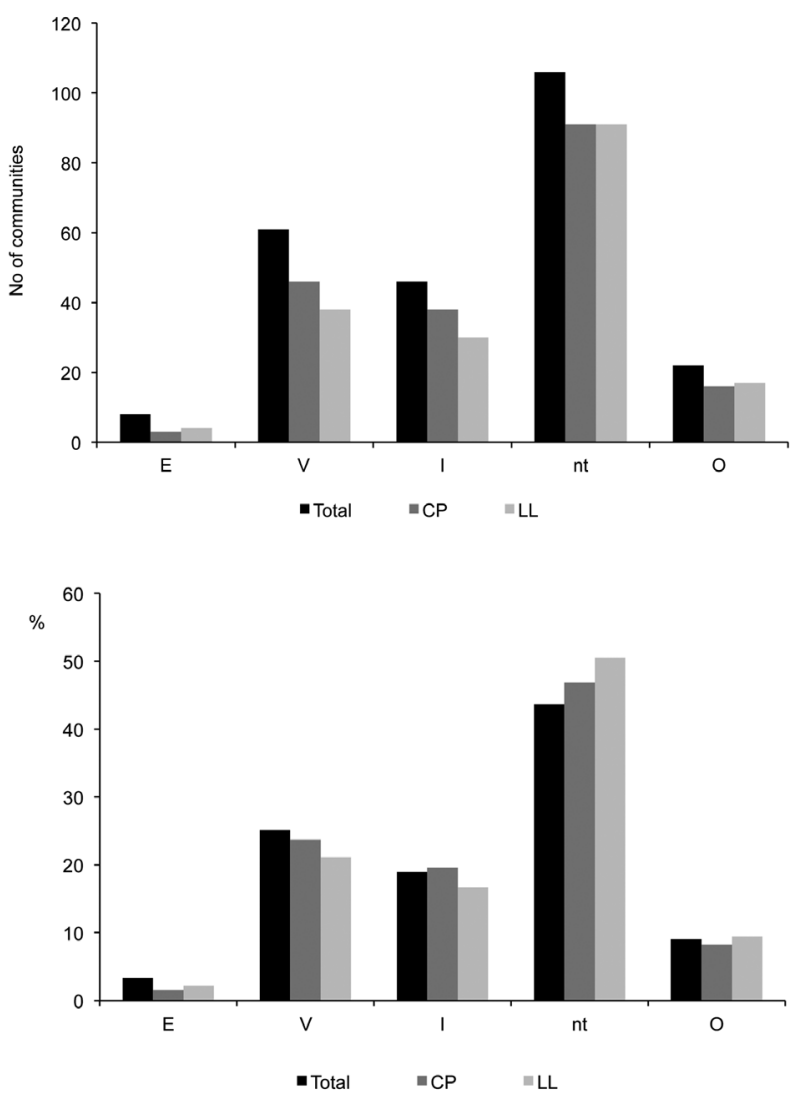

Fig. 4. The number and share of communities representing different categories of dynamic tendencies under human impact in central Pomerania (CP) and Lubuskie Lakeland (LL)

Explanations: category of threat in Poland, E - endangered, V - vulnerable, $\mathrm{I}$ - not determined; nt - not threatened communities, $\mathrm{O}$ - communities expanding their range 
ovinae, Caricetum distichae, Ceratophylletum submersi, Leersietum oryzoidis, Riccietum fluitantis and Ricciocarpetum natantis. Among natural perdochoric (15), more frequent were only Galio sylvatici-Carpinetum and Querco-Ulmetum, whereas the others were noted rarely (e.g. Calletum palustris, Caricetum lasiocarpae, Caricetum remotae, Sagittario-Sparganietum emersi). Within the group of vulnerable communities of seminatural origin astonishingly frequent were phytocoenoses of Arrhenatheretum elatioris (197 notices), much more rare were Angelico-Cirsietum oleracei (18), Sclerantho-Herniarietum glabrae (15) and Junco compressi-Trifolietum repentis (=Blysmo-Juncetum compressi) -13 . Among the rarest communities of this group, Filagini-Vulpietum (4), Polygalo-Nardetum (4) and Caretum carvi (1) can be mentioned.

The group of vulnerable comprised also synanthropic communities, typical of the rural landscape: segetal and ruderal ones. Relatively frequent in the investigated areas were two weed associations of the sub-Atlantic range: Aphano-Matricarietum (noted in 43 spatial complexes) and Veronico agrestis-Fumarietum officinalis (23). Sclerantho-Arnoseridetum minimae, representing a similar type of geographical distribution, but connected with poorer habitats, occurred rarely (7), whereas Spergulo-Chrysanthemetum segetum, Oxalido-Chenopodietum polyspermi and RanunculoMyosuretum were noted only sporadically. Among ruderal communities, Rumicetum obtusifolii was quite frequent (82 notices), while two others: Onopordetum acanthii (12) and Lactuco-Anthriscetum caucalidis (10) - fairly rare.

The heterogenic group of syntaxa representing the category of not determined threat (I), comprised 45 associations which were either poorly documented or with not fully recognized dynamic tendencies under human impact. In this group prevailed communities of natural origin (28), synanthropic ruderal (10) were less numerous, whereas segetal (4) and seminatural (3) were sparse. Several communities stated in the studied villages were assessed as rare (R) and very rare (RR) in the Polish Lowland (Fig. 5). Data on some of them were recently published (Brzeg et al. 2014a). The analysis has shown that the share of rare and extremely rare communities was higher in central Pomerania, whereas common syntaxa prevailed in the Lubuskie Lakeland.

The group of 48 communities found only in the Lubuskie Lakeland included those which were frequent there (e.g., Hordeetum murini noted in $28 \%$ of complexes, Galio aparines-Veronicetum sublobatae - 21.4\%, and Chaerophylletum bulbosi - 17.9\%), rare (e.g. Falcario-Agropyretum - 5.4\%, Lactuco-Anthriscetum caucalidis $-4.5 \%$, Lycietum halimifolii-4.0\%, ErodioSenecionetum vernalis - $2.7 \%$, Poo-Oxalidetum corniculatae $-2.2 \%$, Panico sanguinalis-Eragrostietum
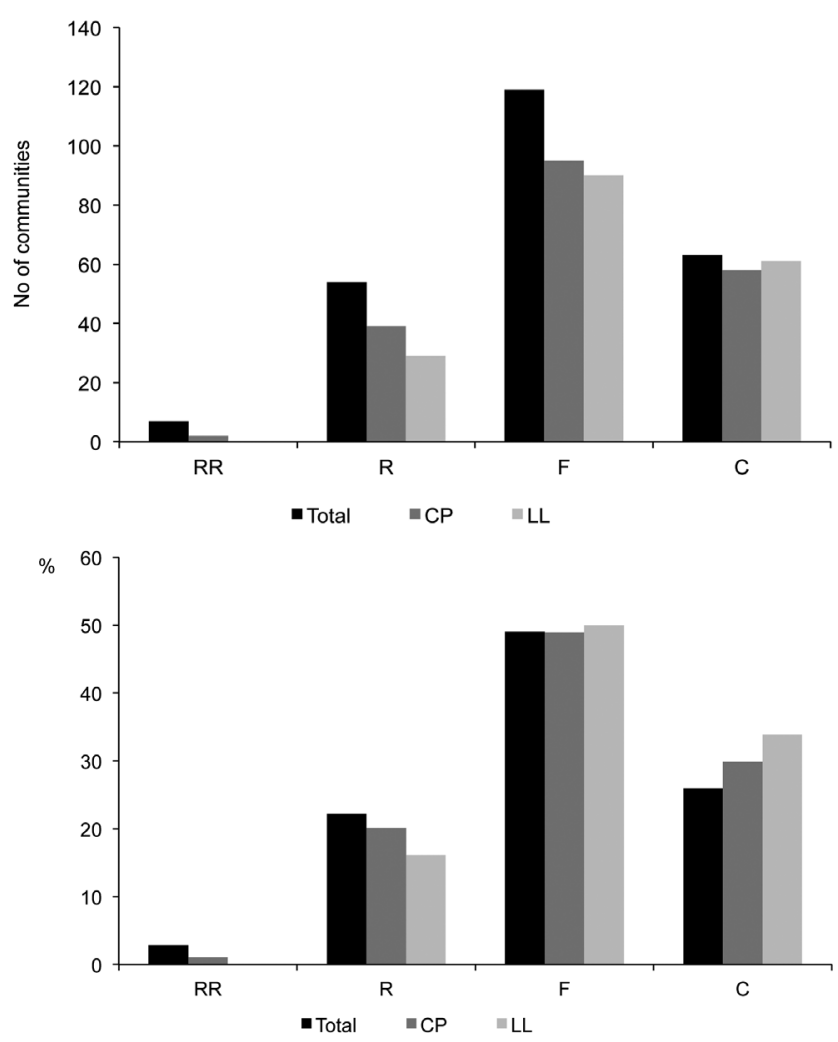

Fig. 5. The number and share of communities representing different categories of frequency in in central Pomerania (CP) and Lubuskie Lakeland (LL)

Explanations: $\mathrm{C}$ - common, $\mathrm{F}$ - frequent, $\mathrm{R}$ - rare, $\mathrm{RR}$ - extremely rare

- $2.2 \%$, and Asplenietum trichomano-rutae-murariae $-1.3 \%$ ), as well as those which were noted sporadically - in less than $1 \%$ of complexes (e.g., Chenopodio glauci-Puccinellietum distantis, Sisymbrio-Atriplicetum nitentis, Centaureo diffusae-Berteroetum, Leersietum oryzoidis, Poo-Coronopodetum squamati, TunicoPoetum compressae).

Among 33 communities found only in Pomerania, only Stellario-Carpinetum (in $10.3 \%$ of complexes) was more frequent. The others were rare, e.g., Lysimachio vulgaris-Filipenduletum (5.5\%), Rubo-Epilobietum angustifolii and Stellario-Alnetum glutinosae (2.1\% each), very rare: Asplenio-Polypodietum and Salicetum auritae (1.4\%), or sporadic - in less than $1 \%$ of complexes: Ammophiletum arenariae, Betulo-Quercetum roboris, Calamagrostietum neglectae, Calletum palustris, Caretum carvi, Glycerio-Sparganietum neglecti, HelichrysoJasionetum litoralis and Spergulo-Chrysanthemetum segetum.

The group of syntaxa observed in both studied regions comprised 162 communities, out of which 10 were frequent and occurred in more than $40 \%$ of complexes. The most common were communities of trodden or grazed areas: Lolio-Plantaginetum (76\%), Poetum annuae (52\%), Lolio-Cynosuretum (50\%) and 
Matricario-Polygonetum arenastri (43\%); mesic meadows - Arrhenatheretum elatioris (65\%); some nitrophilous tall-herb communities: Agropyro-Aegopodietum (64\%), Anthriscetum sylvestris (41\%) and Elymus repens-Urtica dioica community (41\%); nitrophilous black elder thickets Aegopodio-Sambucetum nigrae $(53 \%)$ and ruderal grassland Convolvulo arvensisAgropyretum repentis (51\%).

\section{Discussion}

The vegetation of agricultural landscape undergoes significant transformations resulting from changing forms of human impact (Poschlod et al. 2005; Baessler \& Klotz 2006). Among communities, which were assessed as endangered in previous regional studies (e.g. Brzeg \& Wojterska 1996, 2001; Celiński et al. 1997) or on a country scale (e.g. Piotrowska 1986; Moravec et al. 1995; Rennwald 2000; Ratyńska et al. 2010), some were frequently noted in the studied rural sites (e.g., Arctietum lappae, Arrhenatheretum elatioris, Papaveretum argemones). Some of them, however, albeit found in many villages, occurred either in very small, singular patches (Aphano-Matricarietum, Arctietum lappae, Chenopodio-Descurainietum sophiae, Rumicetum obtusifolii, Scirpetum sylvatici, Veronico agrestis-Fumarietum officinalis) or with an impoverished floristic list (Airo caryophylleae-Festucetum ovinae, Filipendulo-Geranietum palustris, Junco compressiTrifolietum repentis, Leonuro-Ballotetum), as well as with a disturbed floristic structure (the majority of patches of Arrhenatheretum elatioris).

The comparison of plant communities of both regions indicates that the structure of their vegetation shows many affinities and the differences are more of qualitative than quantitative character.

Some natural and endangered communities can find refuge in anthropogenic habitats in settlements, especially in the central green area, on old walls, in ponds and ditches, on wastelands and abandoned fields and in gravel pits. Similar phenomena concerning both vegetation and flora have been reported by Bosiacka \& Pieńkowski (2004); Nowak (2005, 2006a, 2006b, 2009); Nowak \& Nowak (2006); Nowak et al. (2007).

In the years 2010-2014, repeated surveys in some villages revealed that some, mainly ruderal communities with diagnostic archaeophytes, distinctly decreased - both in the number of patches and their size (e.g., Hyoscyamo-Malvetum neglectae, Leonuro-Ballotetum, Matricario-Anthemidetum cotulae, Onopordetum acanthii, Urtico urentis-Chenopodietum boni-henrici). There are several reasons for this phenomenon: 1) giving up raising poultry and other farm animals resulting in the decrease of eutrophication and small scale disturbances,
2) new forms of human impact in villages, e.g., frequent and detailed mowing of lawns, laying of pavements, implementation of herbicides against spontaneous vegetation, intensification of car traffic, and 3) decline of traditional rural habitats: roadsides, linear areas along fences and farm buildings, large unpaved courtyards etc.

At the same time, it can be observed an increase in the share of more thermophilous ruderal communities with expansive kenophytes, such as: ErigerontoBryetum, Erigeronto-Lactucetum serriolae, Panico sanguinalis-Eragrostietum, Polygono arenastri-Portulacetum oleracei, Poo-Oxalidetum corniculatae, and communities connected until now mainly with towns: Bryo-Saginetum procumbentis, Hordeetum murini and Polygonetum calcati (Balcerkiewicz 2000; Borysiak et al. 2000; Brzeg 2009; Szrama 2009).

Some of plant communities, considered as common or frequent on a national scale (Ratyńska et al. 2010), were rare in the study areas. To this category belonged, e.g.: Chaerophylletum aromatici, Chenopodio-Descurainietum sophiae, Onopordetum acanthii, OxalidoChenopodietum polyspermi, Torilidetum japonicae and Vicietum tetraspermae. On the other hand, rare in the Polish lowland Matricarietum discoideo-recutitae was quite frequent there. The status of threat to selected seminatural, segetal and ruderal communities should be therefore reconsidered. Insignificant representation of communities of poor habitats, e.g.: Corniculario-Corynephoretum, Digitarietum ischaemi, Linario-Brometum tectorum or Sclerantho-Arnoseridetum minimae, indicates that mediaeval villages were located exclusively in richer habitats. This observation confirms opinions of Burszta (1958) and Szulc (1995) formulated upon analysis of abiotic conditions.

In spite of the long lasting human impact, rare and endangered plant communities still constitute an important part of the list of stated syntaxa. Similar observations were published from German villages (Steube \& Brandes 2004) and from other types of anthropogenically transformed habitats in Pomerania (Bosiacka, Pieńkowski 2004) and Silesia (Nowak 2006a; Nowak et al. 2007). The importance of anthropogenic habitats in the preservation of diversity of plant cover is therefore the subject of current interest.

\section{Conclusions}

- The rural landscape of both studied areas is still rich and diversified, it hosts many different types of communities, among them natural perdochoric, very rare and endangered, but they constitute only a small percentage of presented lists.

- New forms of human impact (e.g., intensive mowing of lawns, implementation of herbicides along 
fences and buildings, introduction of pavements on farmyards and roadsides), as well as abandonment of cultivation or its intensification are leading to the transformations of the rural landscape, its unification and impoverishment in natural and synanthropic ruderal elements replaced by synanthropic ruderal specialised ones.

- The comparison of both studied regions - central Pomerania and the Lubuskie Lakeland has shown: (i) similar pattern of vegetation differentiation in relation to the origin and degree of threat; (ii) slightly higher vegetation diversity in the villages of central Pomerania.

- Ruderal communities were noted in all types of spatial-functional complexes, whereas segetal com- munities were restricted to meadows, fields and built up areas.

- The rural landscape of the Lubuskie Lakeland was more transformed, richer in ruderal communities, whereas in central Pomerania, natural and seminatural communities were more represented.

- Data gathered from, until now, very scarcely studied landscapes give foundations for the verification of frequency categories and threat to communities in Poland.

Acknowledgments. The investigations were supported by National Science Center Grant NN 305 062440. The authors are very grateful for valuable comments given by two anonymous reviewers, which substantially contributed to the amelioration of quality of this paper.

\section{References}

Aniol-KwiatkowsKa J. 1974. Flora i zbiorowiska synantropijne Legnicy, Lubina i Polkowic. Acta Uniw. Wrat. Prace Bot. 19: 3-152.

Aniol-KwiatKowska J. 1990. Zbiorowiska segetalne Wału Trzebnickiego. Florystyczno-ekologiczne studium porównawcze. Acta Univ. Wrat. Prace Bot. 44: 3-230.

BAessler C. \& Klotz S. 2006. Effects of changes in agricultural land-use on landscape structure and arable weed vegetation over the last 50 years. Agriculture, Ecosystems and Environment 115: 43-50.

Balcerkiewicz S. 2000. The Response of Vegetation to the Hyperanthropopressure, with Reference to Classification of Plant Communities According to the Role of Man in their Origin and Persistence. In: B. JACKOWIAK \& W. ŻUKOWSKI (eds.). Mechanisms of Anthropogenic Changes of the Plant Cover. Publications of the Department of Plant Taxonomy UAM 10: 39-54. Bogucki Wyd. Nauk., Poznań.

Balcerkiewicz S. \& Pawlak G. 1978. Matricario-Alchemilletum R. Tx. 1937 em. Pass. 1957 w uprawach rzepaku na Pomorzu Szczecińskim. Bad. Fizjogr. Pol. Zach. Ser. B-Botanika 30: 83-87.

Balcerkiewicz S. \& Pawlak G. 1990. Materiały do znajomości zbiorowisk chwastów segetalnych na obszarze Borów Skwierzyńskich. Bad. Fizjogr. Pol. Zach. Ser. B-Botanika 40: 121-126.

Balcerkiewicz S., Brzeg A. \& Pawlak G. 1996. Próba geobotaniczno-krajobrazowej charakterystyki obszarów użytkowanych rolniczo przy zastosowaniu koncepcji sigmasocjacji. Zesz. Nauk. WSP Bydgoszcz 12: 17-43.

Borowiec S., Kutyna I. \& Skrzyczyńska J. 1974. Zróżnicowanie zbiorowisk chwastów Niziny Pyrzyckiej na tle warunków ekologicznych. Zesz. Nauk. AR w Szczecinie 42(11): 25-45.

Borowiec S., KuTYNA I. \& SkrZyCZyŃSKA J. 1977. Occurrence of cropfield weed associations against environmen- tal conditions in West Pomerania. Ekol. Pol. 25(2): 257-273.

Borysiak J., Kasprowicz M. \& Pawlak G. 2000. Roślinność rzeczywista miasta Pniewy na Pojezierzu Poznańskim w ujęciu fitosocjologicznym i kartograficznym. Bad. Fizjogr. Pol. Zach. Ser. B-Botanika 49: 173-184.

Bosiacka B. \& Pieńkowski P. 2004. Analiza przekształceń oczek wodnych oraz ocena walorów przyrodniczych śródpolnych zbiorników w centralnej części Równiny Nowogardzkiej. Woda-Środowisko-Obszary wiejskie 4(2a)(11): 335-349.

BRzEG A. 1991. Roślinność segetalna upraw okopowych w Smołdzińskim Lesie (Pobrzeże Słowińskie). Sprawozd. PTPN, Wydz. Mat.-Przyr. 108: 20-24.

BRzEG A. 2009. O występowaniu w Wielkopolsce niektórych rzadkich lub mało znanych zbiorowisk synantropijnych. Cz. III. Saginion procumbentis R.Tx. et Ohba in Géhu et al. 1972. Bad. Fizjogr. Pol. Zach. Ser. BBotanika 58: 89-112.

BrZeg A. \& RosADZiŃSKi S. 2006. Zespół rumianu psiego Matricario-Anthemidetum cotulae Dihoru 1975 ex Mucina 1987 w Kotlinie Zasieckiej (Niziny Sasko-Łużyckie). Bad. Fizjogr. Pol. Zach. Ser. B-Botanika 55: 91-98.

Brzeg A. \& RosAdZIŃski S. 2013. Nowe stanowiska zespołu ostu zwisłego Carduetum nutantis (Săvulescu 1927) Morariu 1943 w zachodniej Polsce. Bad. Fizjogr. Ser. B-Botanika. 4(B62): 53-69.

Brzeg A., Szrama K. \& Wojterska M. 2013. Rzadsze gatunki flory naczyniowej terenów wiejskich Pojezierza Lubuskiego. Bad. Fizjogr. Ser. B-Botanika 4(B62): 145-158.

Brzeg A., Szrama K. \& Wojterska M. 2014a. Matricarietum discoideo-recutitae Jarolímek et al. 1997 and Matricario-Anthemidetum cotulae Dihoru 1975 ex Mucina 1987 - two poorly known associations from the Malvion neglectae (Gutte 1966) Hejný 1978 alliance in rural areas of North-West Poland. Steciana 18(1): 21-28. 
Brzeg A., Szrama K. \& Wojterska M. 2014b. Rzadsze gatunki flory naczyniowej terenów wiejskich Pojezierza Lubuskiego. Cz. II. Bad. Fizjogr. Ser. B-Botanika 5(B63): 117-130.

Brzeg A. \& Wojterska M. 1996. Przegląd systematyczny zbiorowisk roślinnych Wielkopolski wraz z oceną stopnia ich zagrożenia. Bad. Fizjogr. Pol. Zach. Ser. B-Botanika 45: 7-40.

BrZeg A. \& Wojterska M. 2001. Zespoły roślinne Wielkopolski, ich stan poznania i zagrożenie. In: M. WoJTERSKA (ed.). Szata roślinna Wielkopolski i Pojezierza Południowopomorskiego. Przewodnik sesji terenowych 52. Zjazdu PTB, 24-28 września 2001, pp. 39-110. Bogucki Wyd. Nauk., Poznań.

BuRszTA J. 1958. Od osady słowiańskiej do wsi współczesnej. O tworzeniu się krajobrazu osadniczego ziem polskich i rozplanowań wsi. 176 pp. Wyd. Zakł. Narodowy im. Ossolińskich, Wrocław.

Celiński F., Wika S. \& Parusel J. B. (eds.) 1997. Czerwona lista zbiorowisk roślinnych Górnego Śląska. Raporty, opinie 2: 38-68.

ĆWIKLIŃSKi E. 1974. Flora i zbiorowiska roślinne terenów kolejowych województwa szczecińskiego. Rozpr. AR Szczecin, 40: 3-149.

FALIŃSKI J. B. 1963. Zbiorowiska dywanowe zachodniej części Niziny Wielkopolsko-Kujawskiej. Acta Soc. Bot. Pol. 32(1): 81-99.

FALIŃSKi J. B. 1966. Antropogeniczna roślinność Puszczy Białowieskiej jako wynik synantropizacji naturalnego kompleksu leśnego. Rozprawy Uniw. Warszawskiego 13. 256 pp. PWN, Warszawa.

FALIŃSKi J. B. 1969. Zbiorowiska autogeniczne i antropogeniczne. Próba określenia i klasyfikacji. Ekol. Pol. B. $15: 173-182$.

FiJAŁKOWSKi D. 1963. Zbiorowiska synantropijne miasta Chełma. Ann. UMCS C 28(13): 291-325.

FIJAŁKOWSKI D. 1967. Zbiorowiska roślin synantropijnych miasta Lublina. Ann. UMCS C 22(17): 195-233.

FiJaŁkowski D. 1978. Synantropy roślinne Lubelszczyzny. 260 pp. PWN, Warszawa-Łódź.

GUS 2016. Użytkowanie gruntów i powierzchnia zasiewów w 2015 roku. Informacja i opracowanie statystyczne, p. 26. Warszawa.

Herbich J. 1982. Zróżnicowanie i antropogeniczne przemiany roślinności Wysoczyzny Staniszewskiej na Pojezierzu Kaszubskim. Monogr. Bot. 63: 1-162.

JACKowiak B., ChMiel J. \& Latowski K. 1990. Zbiorowiska segetalne zbóż ozimych Wielkopolski. Bad. Fizjogr. Pol. Zach. Ser. B-Botanika 43: 105-124.

JASIŃSKA K., BRZEG A. \& WoJTERSKA M. 2015. Anthropophytes in the flora of different spatial units within old rural settlements of the Lubuskie Lakeland, western Poland. Biodiv. Res. Conserv. 39: 19-32.

KĘPCZYŃSKA-RIJKEN M. 1977. Spatial complexes of ruderal communities in town. Phytocoenosis 6: 229-327.

KĘPCZYŃSKI 1975. Zbiorowiska roślin synantropijnych na terenie miasta Bydgoszczy. Acta Univ. N. Copernici Ser. Biologia 17(36): 3-87.
KęPCZYŃSKi K. \& MarsZAŁKIEwiCZ E. 1977. Zbiorowiska ruderalne miasta Tucholi. Acta Univ. N. Copernici Biol. 20(42): 73-105.

Kornaś J. 1968a. Zespoły roślinne Gorców. II. Zespoły synantropijne. Fragm. Flor. Geobot. 14: 83-124.

KornAś J. 1968b. Geograficzno-historyczna klasyfikacja roślin synantropijnych. Mat. Zakł. Fitosoc. Stos. Uniw. Warszawskiego 25: 33-41.

Kutyna I. 1988. Zachwaszczenie roślin uprawnych oraz zbiorowiska segetalne zachodniej części Kotliny Gorzowskiej i terenów przyległych. Wyd. AR w Szczecinie. 116 pp. Szczecin.

LiBBERT W. 1932. Die Vegetationseinheiten den neumärkischen Staubeckenlandschaft unter Berücksichtigung der angrenzenden Landschaften. 1. Verh. Bot. Ver. Prov. Brandenburg 74: 10-93.

Misiewicz J. 1976. Flora synantropijna i zbiorowiska ruderalne polskich portów morskich. 321 pp. WSP, Słupsk.

Moravec J., Balátová-TuláčKová E., BlažKová D., HadaČ E., HejnÝ S., HusÁk Š., Jeník J., Kolbek J., Krahuled F., Kropáč Z., NeuhäUsl R., Rybníček K., ŘehoŘEK V. \& VICHEREK J. 1995. Rostlinná společenstva České republiky a jejich ohrožení. Ed. 2. Severočeskou Přír., Př́l. pp. 1-206.

NowAK A. 2005. Występowanie rzadkich i ginących roślin naczyniowych na siedliskach antropogenicznych Śląska Opolskiego. Fragm. Flor. Geobot. Polonica 12(1): 223-238.

NowaK A. 2006a. Anthropogenic water bodies as a refugees for rare and threatened pondweed communities in Opole Silesia. In: P. KoČÁreK, V. PlášEK \& K. MalaCHOVÁ (eds). Environmental changes and biological assessment III, pp. 57-65. Scripta Facultatis Rerum Naturalium Universitatis Ostraviensis.

NowAK A. 2006b. Sozophytes (red-listed species) in Silesian anthropogenic habitats and their role in nature conservation. Biodiv. Res. Conserv. 3-4: 386-390.

NowAK A. 2009. Synanthropization of sozophytes in Silesia by allochthonization analysis of the plant communities. In: Z. MireK \& A. Nikel (eds.). Rare, relict and endangered plants and fungi in Poland, pp. 335-343. W. Szafer Institute of Botany, Polish Academy of Science, Kraków.

NowaK A. \& NowaK S. 2006. Anthropogenic habitats can shelter threatened plants. In: D. GAFtA \& J. Akeroyd (eds.). Nature Conservation. Concepts and Practice, pp. 107-115. Springer-Verlag, Berlin Heidelberg.

NowaK A., NowaK S. \& CZERniaWSKA-Kusza I. 2007. Rare and threatened pondweed communities in anthropogenic water bodies of Opole Silesia (SW Poland). Acta Soc. Bot. Pol. 76(2): 151-163.

Nowiński M. 1964. Chwasty segetalne Wyspy Wolin. Prace Kom. Biol. PTPN 22(6): 3-38.

Nowiński M. 1965. Chwasty segetalne Łeby i okolicy w województwie gdańskim. PTPN Prace Kom. Nauk Roln. i Kom. Nauk Leśn. 19(2): 303-351.

Passarge H. 1963. Beobachtungen über Pflanzengesellschaften Landwirtschaftlicher Nutzflächen in nordlichen Polen. Feddes Repert. 140(5): 27-69. 
PAWLAK G. 1980. Materiały do poznania zbiorowisk antropogenicznych okolic Lubniewic na Pojezierzu Lubuskim. Bad. Fizjogr. Pol. Zach. Ser. B-Botanika 31: 131-146.

PAWLAK G. 1981. Roślinność synantropijna obszaru wybitnie rolniczego na przykładzie okolic wsi Kłodzino w województwie szczecińskim. PTPN Prace Kom. Biol. 56: 1-80.

Pender K. 1990. Lasy obszarów Wzgórz Strzelińskich i ich zbiorowiska zastępcze. II. Zbiorowiska zastępcze. Acta Uniw. Wrat. Prace Bot. 44:141-225.

Piotrowska H. 1986. Gefährdungssituation der Pflanzengesellschaften der planaren und kollinen Stufe Polens (Erste Fassung). Schriftenreihe f. Vegetationskunde 18: 19-27.

Poschlod P., Bakker J. P. \& Kahmen S. 2005. Changing land use and its impact on biodiversity. Basic Appl. Ecol. 6: 93-98.

RATUSZNIAK I. \& Sobisz Z. 1999. Zbiorowiska segetalne Parku Krajobrazowego “Dolina Słupi”. Część I. Bad. Fizjogr. Pol. Zach. Ser. B-Botanika 48: 97-110.

RATUSZNIAK I. \& SoBisz Z. 2000. Zbiorowiska segetalne upraw warzywnych i okopowych wybranych gospodarstw ekologicznych Pomorza Zachodniego. Pamiętnik Puławski 122: 113-123.

RAtuszniak I. \& Sobisz Z. 2001. Zbiorowiska segetalne Parku Krajobrazowego “Dolina Słupi”. Część II. Bad. Fizjogr. Pol. Zach. Ser. B-Botanika 50: 63-79.

RATUSZNiAK I., SoBisz Z. 2004. Zbiorowiska segetalne Parku Krajobrazowego "Dolina Słupi”. Część III. Bad. Fizjogr. Pol. Zach. Ser. B-Botanika 53: 39-57.

RATUSZNiAK I., SoBisz Z. 2005. Zbiorowiska segetalne Parku Krajobrazowego "Dolina Słupi”. Część IV. Bad. Fizjogr. Pol. Zach. Ser. B-Botanika 54: 67-82.

RatyŃska H., Wojterska M., Brzeg A. \& KoŁacz M. 2010. Multimedialna encyklopedia zbiorowisk roślinnych Polski ver. 1.1. Inst. Eduk. Techn. Inf. UKW, Bydgoszcz.

RĄCZKOWSKI W. 1995. Aerial Archaeology and the Study of Settlement Systems: some examples from the Middle Pomerania (Poland). In: J. Kunow (ed.). Luftbildarchäologie in Ost- und Mitteleuropa, Forschungen zur Archäologie im Land Brandenburg 3, pp. 265270. Brandenburgisches Landesmuseum für Ur- und Frühgeshichte, Potsdam.

RĄCZKOWSKI W. 2002. Archeologia w krajobrazie kulturowym, In: W. Rączkowski \& J. Sroka (eds.). De rebus futuris memento: przyszłość przeszłego krajobrazu kulturowego Ziemi Sławieńskiej, pp. 69-78. Fundacja Dziedzictwo, Sławieński Dom Kultury, Sławno.

Rennwald E. (ed.) 2000. Verzeichnis und Rote Liste der Pflanzengesellschaften Deutschlands. Schriftenreihe f. Vegetationskunde 35, pp. 800. Bonn-Bad Godesberg.

Rostański K. \& GutTe P. 1971. Roślinność ruderalna miasta Wrocławia. Mat. Zakł. Fitosoc. Stos. Uniw. Warszawskiego 27: 167-215.

SicıŃSKi J. T. 1974. Zbiorowiska segetalne Kotliny Szczercowskiej (Widawskiej). Acta Agrobot. 27(1): 91-112.

SiciŃSKi J. T. 1994. Conservation of flora and segetal communities in Poland. In: S. MochnackỲ \& A. TerPó (red.). Antropization and environment of rural settlements.
Flora and vegetation. Proceedings of International Conference, Sátoraljaújhely, 22-26 August 1994, pp. 149-153.

SoBisz Z. 1996. Spergulo-Chrysanthemetum segeti (Br.Bl. et De Leeuw 1936) R. Tx. 1937 na Równinie Słupskiej i Wysoczyźnie Damnickiej. Bad. Fizjogr. Pol. Zach. Ser. B-Botanika 45: 159-166.

SoBISz Z. 2006. Spergulo-Chrysanthemetum segeti (Br.Bl. et De Leeuw 1936) R. Tx. 1937 on the Słowińskie Coast. Rocz. AR Pozn., Botanika-Steciana 10: 165-176.

SoBisz Z. 2007. Spergulo-Chrysanthemetum segeti (Br.Bl. et De Leeuw 1936) R. Tx. 1937 na Pojezierzu Bytowskim. Słupskie Pr. Biol. 4: 109-122.

SoBisz Z. 2012. Spergulo-Chrysanthemetum segeti (Br. Bl. et De Leeuw 1936) R. Tx. 1937 na Równinie Białogardzkiej. Słupskie Pr. Biol. 9: 143-154.

Sowa R. 1971. Flora i roślinne zbiorowiska ruderalne na obszarze województwa łódzkiego ze szczególnym uwzględnieniem miast i miasteczek. 282 pp. Uniw. Łódzki, Łódź.

Steube U. \& Brandes D. 2004. Untersuchungen zur Mauerflora von Dörfern im Kreis Halberstadt (SachsenAnhalt). Working Group for Vegetation Ecology, Institute of Plant Biology, Technical University Braunschweig, D-38023 Braunschweig, http://www.ruderalvegetation.de/epub/

SzRama K. 2009. Rzadsze zbiorowiska ruderalne Słupcy i okolic z udziałem ciepłolubnych gatunków synantropijnych. Bad. Fizjogr. Pol. Zach. Ser. B-Botanika 58: 113-126.

SzRAMA K. \& BRZEG A. 2011. Zbiorowiska ruderalnych ziołoi traworośli z rzędu Onopordetalia acanthii Br.-Bl. et R. Tx. 1943 em. R. Tx. 1950 Stupcy i okolic. Bad. Fizjogr. Pol. Zach. Ser. B-Botanika 2(B60): 103-135.

Szulc H. 1995. Morfogeneza osiedli wiejskich w Polsce. Prace Geogr. IGiPZ PAN 163: 1-112.

TOKARska-GuZiK B., Dajdok Z., ZająC M., Urbisz A. \& DANIELEWICZ W. 2011. Identyfikacja i kategoryzacja roślin obcego pochodzenia jako podstawa działań praktycznych. In: Z. KĄCKI \& E. STEFAŃSKA-KRZACZEK (eds.). Synantropizacja $\mathrm{w}$ dobie zmian różnorodności biologicznej. Acta Bot. Silesiaca 6: 23-53.

WARChOLIŃSKA A. U. 1987. Zbiorowiska segetalne Wzgórz Radomszczańskich. Bad. Fizjogr. Pol. Zach., Ser. BBotanika 38: 123-153.

Wojterska M. 2003. Struktura krajobrazów roślinnych Pojezierza Międzychodzko-Sierakowskiego. 415 pp. Bogucki Wyd. Nauk. Poznań.

Wojterska M., Ratyńska H. \& RączKowski W. 2007. Współczesna struktura krajobrazu roślinnego średniowiecznych założeń osadniczych w zachodniej Polsce. In: W. Dreszer (ed.) Sztuka projektowania krajobrazu. Materiały z międzyuczelnianej konferencji "Architektura krajobrazu kulturowego", pp. 74-79. ASP, Poznań.

Wóscik Z. 1998. Zbiorowiska segetalne Pogórza Przemyskiego i jego najbliższego otoczenia. Fragm. Flor. Geobot. Polonica 5: 117-164.

ZAJĄC A. U. 1974. Ruderal vegetation of the Bielsko-Biała town. Monogr. Bot. 40: 1-88. 
Appendix 1. List of plant communities occurring in the studied complexes in villages and their surroundings

\begin{tabular}{|c|c|c|c|c|c|c|c|}
\hline \multirow[t]{3}{*}{ No } & 1 & 2 & 3 & 4 & 5 & 6 & 7 \\
\hline & Number of villages & 48 & 18 & 18 & & & \\
\hline & Area & Total & $\mathrm{CP}$ & LL & & & \\
\hline & \multicolumn{7}{|l|}{ Forest and shrub communities } \\
\hline 1 & Carici elongatae-Alnetum & 5 & 3 & 1 & $\mathrm{~N}$ & $\mathrm{nt}$ & $\mathrm{F}$ \\
\hline 2 & Salicetum cinereae & 55 & 33 & 10 & NA & $\mathrm{nt}$ & $\mathrm{F}$ \\
\hline 3 & Salicetum auritae & 2 & 2 & 0 & NA & I & $\mathrm{R}$ \\
\hline 4 & Salicetum albae & 9 & 1 & 5 & NP & $\mathrm{V}$ & $\mathrm{R}$ \\
\hline 5 & Salicetum triandro-viminalis & 3 & 1 & 1 & NA & $\mathrm{nt}$ & $\mathrm{F}$ \\
\hline 6 & Calamagrostio arundinaceae-Quercetum petraeae & 7 & 7 & 0 & NP & I & $\mathrm{F}$ \\
\hline 7 & Molinio caeruleae-Quercetum roboris & 1 & 1 & 0 & NP & $\mathrm{V}$ & $\mathrm{R}$ \\
\hline 8 & Betulo-Quercetum roboris & 1 & 1 & 0 & NP & $\mathrm{V}$ & $\mathrm{R}$ \\
\hline 9 & Fraxino-Alnetum & 13 & 8 & 2 & $\mathrm{~N}$ & I & $\mathrm{F}$ \\
\hline 10 & Stellario-Alnetum glutinosae & 3 & 3 & 0 & NP & $\mathrm{V}$ & $\mathrm{RR}$ \\
\hline 11 & Querco-Ulmetum & 33 & 11 & 11 & NP & $\mathrm{V}$ & $\mathrm{F}$ \\
\hline 12 & Galio sylvatici-Carpinetum & 17 & 0 & 6 & NP & $\mathrm{V}$ & $\mathrm{F}$ \\
\hline 13 & Stellario holosteae-Carpinetum & 16 & 16 & 0 & NP & $\mathrm{V}$ & $\mathrm{F}$ \\
\hline 14 & Deschampsio flexuosae-Fagetum & 1 & 0 & 0 & NP & I & $\mathrm{F}$ \\
\hline 15 & Melico uniflorae-Fagetum & 2 & 1 & 0 & NP & $\mathrm{V}$ & $\mathrm{F}$ \\
\hline 16 & Adoxo-Aceretum pseudoplatani & 1 & 0 & 0 & NP & $\mathrm{E}$ & $\mathrm{RR}$ \\
\hline 17 & Chelidonio-Robinietum & 39 & 2 & 21 & SR & $\mathrm{nt}$ & $\mathrm{F}$ \\
\hline 18 & Euonymo-Prunetum spinosae & 75 & 20 & 31 & NA & $\mathrm{nt}$ & $\mathrm{C}$ \\
\hline 19 & Aegopodio-Sambucetum nigrae & 165 & 51 & 67 & NA & $\mathrm{nt}$ & $\mathrm{C}$ \\
\hline 20 & Euonymo-Cornetum sanguinei & 3 & 1 & 1 & NA & I & $\mathrm{F}$ \\
\hline 21 & Euonymo-Coryletum & 11 & 4 & 5 & NA & I & $\mathrm{F}$ \\
\hline 22 & Pruno-Ligustretum & 3 & 0 & 2 & $\mathrm{~N}$ & $\mathrm{~V}$ & $\mathrm{R}$ \\
\hline 23 & Rosetum rubiginoso-dumalis & 4 & 1 & 2 & NA & $\mathrm{V}$ & $\mathrm{R}$ \\
\hline 24 & Rubo plicati-Sarothamnetum & 14 & 8 & 2 & NA & I & $\mathrm{F}$ \\
\hline 25 & Agrostio-Populetum tremulae & 18 & 7 & 5 & NA & $\mathrm{nt}$ & $\mathrm{F}$ \\
\hline 26 & Comm. Rubus gracilis-R. plicatus pro ass. & 13 & 2 & 6 & NA & $\mathrm{nt}$ & $\mathrm{F}$ \\
\hline \multirow[t]{2}{*}{27} & Comm. Ammophila arenaria-Rosa rugosa & 1 & 1 & 0 & $\mathrm{X}$ & $\mathrm{nt}$ & $\mathrm{R}$ \\
\hline & \multicolumn{7}{|c|}{ Communities of stages of forest development and clear cuttings } \\
\hline 28 & Calamagrostietum epigeji & 8 & 2 & 1 & NA & $\mathrm{nt}$ & $\mathrm{C}$ \\
\hline 29 & Rubo-Epilobietum angustifolii & 3 & 3 & 0 & NA & nt & $\mathrm{F}$ \\
\hline 30 & Salicetum capreae & 28 & 8 & 10 & NA & $\mathrm{V}$ & $\mathrm{R}$ \\
\hline \multirow[t]{2}{*}{31} & Rubetum idaei & 32 & 17 & 7 & NA & nt & $\mathrm{C}$ \\
\hline & \multicolumn{7}{|l|}{ Water and swamp communities } \\
\hline 32 & Lemnetum minoris & 38 & 17 & 15 & NA & nt & $\mathrm{C}$ \\
\hline 33 & Lemnetum trisulcae & 11 & 3 & 4 & NA & $\mathrm{nt}$ & $\mathrm{F}$ \\
\hline 34 & Callitricho-Lemnetum minoris & 5 & 3 & 2 & NA & I & $\mathrm{F}$ \\
\hline 35 & Lemno-Spirodeletum polyrhizae & 11 & 6 & 1 & NA & $\mathrm{nt}$ & $\mathrm{C}$ \\
\hline 36 & Riccietum fluitantis & 3 & 1 & 2 & NA & $\mathrm{V}$ & $\mathrm{R}$ \\
\hline 37 & Ricciocarpetum natantis & 1 & 0 & 0 & NA & $\mathrm{V}$ & $\mathrm{RR}$ \\
\hline 38 & Lemno-Hydrocharitetum morsus-ranae & 2 & 2 & 0 & NA & I & $\mathrm{F}$ \\
\hline 39 & Lemno-Utricularietum vulgaris & 5 & 2 & 2 & NA & I & $\mathrm{F}$ \\
\hline 40 & Ceratophylletum demersi & 9 & 1 & 6 & NA & $\mathrm{nt}$ & $\mathrm{C}$ \\
\hline 41 & Ceratophylletum submersi & 2 & 0 & 2 & NA & $\mathrm{V}$ & $\mathrm{R}$ \\
\hline 42 & Myriophyletum spicati & 1 & 0 & 0 & $\mathrm{~N}$ & I & $\mathrm{F}$ \\
\hline 43 & Potametum crispi & 1 & 0 & 0 & NA & I & $\mathrm{F}$ \\
\hline 44 & Zannichellietum palustris & 1 & 0 & 0 & $\mathrm{~N}$ & $\mathrm{~V}$ & $\mathrm{R}$ \\
\hline 45 & Elodeetum canadensis & 6 & 6 & 0 & $\mathrm{X}$ & $\mathrm{O}$ & $\mathrm{F}$ \\
\hline 46 & Polygonetum natantis & 5 & 0 & 3 & NA & $\mathrm{nt}$ & $\mathrm{F}$ \\
\hline 47 & Potametum natantis & 12 & 5 & 6 & NA & nt & $\mathrm{F}$ \\
\hline 48 & Nymphaeo albae-Nupharetum luteae & 7 & 3 & 0 & $\mathrm{~N}$ & $\mathrm{~V}$ & $\mathrm{~F}$ \\
\hline 49 & Hottonietum palustris & 1 & 0 & 0 & NA & I & $\mathrm{F}$ \\
\hline 50 & Beruletum submersae & 1 & 0 & 1 & NA & $\mathrm{V}$ & $\mathrm{R}$ \\
\hline
\end{tabular}




\begin{tabular}{|c|c|c|c|c|c|c|c|}
\hline \multirow[t]{3}{*}{ No } & 1 & 2 & 3 & 4 & 5 & 6 & 7 \\
\hline & Number of villages & 48 & 18 & 18 & & & \\
\hline & Area & Total & $\mathrm{CP}$ & LL & & & \\
\hline 51 & Caricetum remotae & 1 & 1 & 0 & NP & $\mathrm{V}$ & $\mathrm{R}$ \\
\hline 52 & Scirpetum lacustris & 2 & 0 & 1 & NA & $\mathrm{nt}$ & $\mathrm{C}$ \\
\hline 53 & Typhetum angustifoliae & 4 & 2 & 2 & NA & $\mathrm{nt}$ & $\mathrm{C}$ \\
\hline 54 & Typhetum latifoliae & 58 & 26 & 18 & NA & $\mathrm{nt}$ & $\mathrm{C}$ \\
\hline 55 & Sparganietum ramosi & 6 & 0 & 3 & NA & nt & $\mathrm{C}$ \\
\hline 56 & Phragmitetum communis & 45 & 15 & 19 & NA & $\mathrm{nt}$ & $\mathrm{C}$ \\
\hline 57 & Equisetetum limosi & 1 & 1 & 0 & NA & $\mathrm{I}$ & $\mathrm{F}$ \\
\hline 58 & Glycerietum maximae & 13 & 10 & 2 & NA & $\mathrm{nt}$ & $\mathrm{C}$ \\
\hline 59 & Acoretum calami & 18 & 8 & 3 & $\mathrm{X}$ & $\mathrm{nt}$ & $\mathrm{C}$ \\
\hline 60 & Cicuto-Caricetum pseudocyperi & 5 & 3 & 2 & NP & $\mathrm{V}$ & $\mathrm{F}$ \\
\hline 61 & Thelypterido-Phragmitetum & 1 & 1 & 0 & NP & nt & $\mathrm{F}$ \\
\hline 62 & Iridetum pseudoacori & 16 & 12 & 1 & NA & I & $\mathrm{C}$ \\
\hline 63 & Caricetum acutiformis & 21 & 6 & 5 & NA & $\mathrm{nt}$ & $\mathrm{C}$ \\
\hline 64 & Caricetum distichae & 9 & 6 & 2 & NA & $\mathrm{V}$ & $\mathrm{R}$ \\
\hline 65 & Caricetum elatae & 12 & 8 & 4 & $\mathrm{~N}$ & $\mathrm{I}$ & $\mathrm{F}$ \\
\hline 66 & Caricetum gracilis & 21 & 12 & 7 & NA & nt & $\mathrm{C}$ \\
\hline 67 & Caricetum paniculatae & 4 & 2 & 2 & $\mathrm{~N}$ & $\mathrm{~V}$ & $\mathrm{~F}$ \\
\hline 68 & Caricetum ripariae & 7 & 0 & 3 & NA & I & $\mathrm{F}$ \\
\hline 69 & Caricetum rostratae & 7 & 5 & 2 & NA & $\mathrm{V}$ & $\mathrm{R}$ \\
\hline 70 & Caricetum vesicariae & 7 & 5 & 1 & NP & $\mathrm{V}$ & $\mathrm{R}$ \\
\hline 71 & Caricetum vulpinae & 3 & 0 & 2 & $\mathrm{~N}$ & $\mathrm{~V}$ & $\mathrm{R}$ \\
\hline 72 & Oenantho aquaticae-Rorippetum amphibiae & 3 & 1 & 0 & NA & nt & $\mathrm{F}$ \\
\hline 73 & Glycerio-Oenanthetum aquaticae & 3 & 1 & 1 & NA & I & $\mathrm{F}$ \\
\hline 74 & Sagittario-Sparganietum emersi & 1 & 1 & 0 & NP & $\mathrm{V}$ & $\mathrm{R}$ \\
\hline 75 & Butometum umbellati & 2 & 1 & 0 & NA & nt & $\mathrm{F}$ \\
\hline 76 & Eleocharitetum palustris & 16 & 6 & 6 & NA & $\mathrm{nt}$ & $\mathrm{F}$ \\
\hline 77 & Glycerio-Sparganietum neglecti & 1 & 1 & 0 & NA & $\mathrm{V}$ & $\mathrm{R}$ \\
\hline 78 & Glycerietum fluitantis & 33 & 17 & 7 & NA & nt & $\mathrm{C}$ \\
\hline 79 & Glycerietum plicatae & 8 & 5 & 2 & NA & $\mathrm{V}$ & $\mathrm{R}$ \\
\hline 80 & Cardamino amarae-Beruletum erecti & 8 & 5 & 3 & NA & I & $\mathrm{F}$ \\
\hline 81 & Leersietum oryzoides & 1 & 0 & 0 & NA & $\mathrm{V}$ & $\mathrm{R}$ \\
\hline 82 & Phalaridetum arundinaceae & 56 & 29 & 18 & NA & $\mathrm{nt}$ & $\mathrm{C}$ \\
\hline 83 & Caricetum lasiocarpae & 1 & 1 & 0 & NP & $\mathrm{V}$ & $\mathrm{R}$ \\
\hline 84 & Calletum palustris & 1 & 1 & 0 & NP & $\mathrm{V}$ & $\mathrm{R}$ \\
\hline 85 & Calamagrostietum canescentis & 3 & 2 & 0 & NA & I & $\mathrm{F}$ \\
\hline 86 & Carici canescentis-Agrostietum caninae & 2 & 1 & 1 & NA & I & $\mathrm{F}$ \\
\hline 87 & Calamagrostietum neglectae & 1 & 1 & 0 & NA & $\mathrm{V}$ & $\mathrm{R}$ \\
\hline \multirow[t]{2}{*}{88} & Caricetum paniceo-lepidocarpae & 2 & 1 & 1 & NA & $\mathrm{V}$ & $\mathrm{R}$ \\
\hline & \multicolumn{7}{|c|}{ Ephemerous therophytic communities on periodically flooded sites } \\
\hline 89 & Ranunculo-Myosuretum & 1 & 0 & 0 & SS & $\mathrm{V}$ & $\mathrm{F}$ \\
\hline 90 & Juncetum bufonii & 8 & 6 & 1 & NA & $\mathrm{nt}$ & $\mathrm{C}$ \\
\hline 91 & Bidenti-Polygonetum hydropiperis & 20 & 11 & 2 & NA & $\mathrm{nt}$ & $\mathrm{C}$ \\
\hline 92 & Rumici-Alopecuretum aequalis & 8 & 1 & 5 & NA & $\mathrm{I}$ & $\mathrm{F}$ \\
\hline 93 & Bidenti-Rumicetum maritimi & 2 & 0 & 0 & NA & $\mathrm{nt}$ & $\mathrm{C}$ \\
\hline 94 & Bidentetum cernui & 8 & 5 & 3 & NA & I & $\mathrm{F}$ \\
\hline 95 & Bidenti-Ranunculetum scelerati & 12 & 3 & 6 & NA & $\mathrm{nt}$ & $\mathrm{F}$ \\
\hline \multirow[t]{2}{*}{96} & Chenopodietum rubri & 1 & 1 & 0 & NA & $\mathrm{nt}$ & $\mathrm{F}$ \\
\hline & \multicolumn{7}{|c|}{ Communities of xerothermophilous swards and tall herbs } \\
\hline 97 & Ammophiletum arenariae & 1 & 1 & 0 & NP & $\mathrm{V}$ & $\mathrm{R}$ \\
\hline 98 & Helichryso arenarii-Jasionetum litoralis & 1 & 1 & 0 & $\mathrm{~N}$ & $\mathrm{~V}$ & $\mathrm{R}$ \\
\hline 99 & Corniculario-Corynephoretum & 3 & 1 & 2 & NA & nt & $\mathrm{C}$ \\
\hline 100 & Filagini-Vulpietum & 4 & 1 & 3 & $\mathrm{SN}$ & $\mathrm{V}$ & $\mathrm{R}$ \\
\hline 101 & Airo caryophylleae-Festucetum ovinae & 8 & 2 & 4 & NA & $\mathrm{V}$ & $\mathrm{R}$ \\
\hline 102 & Sclerantho polycarpi-Herniarietum glabrae & 15 & 9 & 3 & $\mathrm{SN}$ & $\mathrm{V}$ & $\mathrm{F}$ \\
\hline 103 & Armerio elongatae-Festucetum ovinae & 15 & 3 & 9 & $\mathrm{SN}$ & $\mathrm{nt}$ & $\mathrm{C}$ \\
\hline
\end{tabular}




\begin{tabular}{llcccccc}
\hline \multirow{2}{*}{ No } & \multicolumn{1}{c}{1} & 2 & 3 & 4 & 5 & 6 & 7 \\
& Number of villages & 48 & 18 & 18 & & & \\
& Area & Total & CP & LL & & & \\
\hline 104 & Comm. Erophila verna-Cerastium semidecandrum & 32 & 1 & 19 & $\mathrm{NA}$ & $\mathrm{nt}$ & $\mathrm{F}$ \\
105 & Arenario-Sedetum acris & 24 & 5 & 7 & $\mathrm{SR}$ & $\mathrm{nt}$ & $\mathrm{F}$ \\
106 & Erodio-Senecionetum vernalis & 6 & 0 & 6 & $\mathrm{SR}$ & $\mathrm{O}$ & $\mathrm{C}$ \\
107 & Saxifrago-Poetum compressae & 1 & 0 & 0 & $\mathrm{SR}$ & $\mathrm{I}$ & $\mathrm{R}$ \\
108 & Sileno otitae-Festucetum trachyphyllae & 3 & 0 & 1 & $\mathrm{NA}$ & $\mathrm{V}$ & $\mathrm{F}$ \\
109 & Tunico-Poetum compressae & 1 & 0 & 1 & $\mathrm{NA}$ & $\mathrm{V}$ & $\mathrm{R}$ \\
110 & Trifolio medii-Agrimonietum & 11 & 3 & 0 & $\mathrm{NA}$ & $\mathrm{nt}$ & $\mathrm{C}$ \\
111 & Agrostio-Agrimonietum procerae & 5 & 2 & 2 & $\mathrm{NA}$ & $\mathrm{I}$ & $\mathrm{R}$ \\
112 & Trifolio-Melampyretum nemorosi & 1 & 0 & 0 & $\mathrm{NA}$ & $\mathrm{nt}$ & $\mathrm{F}$ \\
113 & Fragario vescae-Campanuletum cervicariae & 1 & 1 & 0 & $\mathrm{~N}$ & $\mathrm{E}$ & $\mathrm{RR}$ \\
114 & Agrimonio-Vicietum cassubicae & 9 & 4 & 3 & $\mathrm{NA}$ & $\mathrm{V}$ & $\mathrm{F}$ \\
115 & Sedo maximi-Peucedanetum oreoselini & 15 & 3 & 9 & $\mathrm{NA}$ & $\mathrm{nt}$ & $\mathrm{F}$ \\
116 & Lathyro-Melampyretum pratensis & 2 & 2 & 0 & $\mathrm{NA}$ & $\mathrm{nt}$ & $\mathrm{F}$ \\
117 & Comm. Agrostis tenuis-Holcus mollis & 11 & 4 & 5 & $\mathrm{NA}$ & $\mathrm{nt}$ & $\mathrm{F}$ \\
\hline
\end{tabular}

Meadow, pasture and heathland communities

118 Filipendulo-Geranietum palustris

119 Lysimachio vulgaris-Filipenduletum

120 Scirpetum sylvatici

121 Angelico-Cirsietum oleracei

122 Caricetum cespitosae

123 Ranunculo repentis-Alopecuretum pratensis

124 Stellario palustris-Deschampsietum cespitosae

125 Epilobio-Juncetum effusi

126 Comm. Ranunculus acris-Lychnis flos-cuculi

127 Comm. Equisetum palustre

128 Comm. Holcus lanatus

129 Arrhenatheretum elatioris

130 Chrysanthemo leucanthemi-Rumicetum thyrsiflori

131 Comm. Poa pratensis-Festuca rubra

132 Lolio perennis-Cynosuretum cristati

133 Caretum carvi

134 Lolio-Plantaginetum

135 Prunello-Plantaginetum

136 Juncetum macri

137 Potentillo-Festucetum arundinaceae

138 Ranunculo repentis-Alopecuretum geniculati

139 Junco compressi-Trifolietum repentis

140 Ranunculetum repentis

141 Mentho longifoliae-Juncetum inflexi

142 Potentilletum anserinae

143 Potentilletum reptantis

144 Polygalo-Nardetum

Communities of rock crevices and walls

145 Asplenietum trichomano-rutae-murariae

146 Cystopteridetum fragilis

147 Gymnocarpietum robertiani

148 Asplenio-Polypodietum

149 Comm. Ceratodon purpureus-Syntrichia ruralis

$\begin{array}{cccccc}20 & 14 & 3 & \text { NA } & \text { V } & \text { F } \\ 8 & 8 & 0 & \text { NA } & \text { nt } & \text { F } \\ 28 & 12 & 6 & \text { N } & \text { V } & \text { F } \\ 18 & 12 & 4 & \text { SN } & \text { V } & \text { F } \\ 1 & 0 & 0 & \text { N } & \text { V } & \text { R } \\ 51 & 36 & 9 & \text { SN } & \text { nt } & \text { F } \\ 21 & 11 & 6 & \text { SN } & \text { nt } & \text { C } \\ 36 & 25 & 6 & \text { SN } & \text { nt } & \text { F } \\ 19 & 13 & 4 & \text { SN } & \text { nt } & \text { F } \\ 3 & 3 & 0 & \text { NA } & \text { I } & \text { R } \\ 21 & 9 & 11 & \text { SN } & \text { nt } & \text { C } \\ 195 & 59 & 83 & \text { SN } & \text { V } & \text { C } \\ 40 & 17 & 13 & \text { SN } & \text { I } & \text { F } \\ 92 & 16 & 41 & \text { SN } & \text { nt } & \text { C } \\ 143 & 58 & 51 & \text { SN } & \text { I } & \text { F } \\ 1 & 1 & 0 & \text { SN } & \text { V } & \text { R } \\ 224 & 76 & 88 & \text { SN } & \text { nt } & \text { C } \\ 5 & 1 & 3 & \text { NA } & \text { I } & \text { F } \\ 3 & 2 & 1 & \text { X } & \text { O } & \text { F } \\ 24 & 10 & 11 & \text { SN } & \text { I } & \text { F } \\ 24 & 18 & 2 & \text { SN } & \text { nt } & \text { F } \\ 13 & 3 & 6 & \text { SN } & \text { V } & \text { R } \\ 119 & 39 & 45 & \text { SN } & \text { nt } & \text { C } \\ 5 & 3 & 2 & \text { NA } & \text { V } & \text { R } \\ 103 & 33 & 46 & \text { SN } & \text { nt } & \text { C } \\ 67 & 3 & 36 & \text { SN } & \text { nt } & \text { C } \\ 4 & 3 & 0 & \text { SN } & \text { V } & \text { R }\end{array}$

Nitrophilous perennial tall herb communities

150 Epilobio hirsuti-Convolvuletum sepium

151 Eupatorietum cannabini

152 Urtico-Convolvuletum sepium

153 Fallopio-Humuletum lupuli

154 Carduo crispi-Rubetum caesii

$\begin{array}{cccccc}3 & 0 & 2 & \text { NA } & \text { E } & \text { R } \\ 1 & 0 & 0 & \text { NA } & \text { E } & \text { RR } \\ 1 & 0 & 0 & \text { N } & \text { E } & \text { RR } \\ 2 & 2 & 0 & \text { N } & \text { V } & \text { R } \\ 33 & 8 & 16 & \text { SRS } & \text { nt } & \text { C }\end{array}$

$\begin{array}{cccccc}26 & 17 & 7 & \text { NA } & \text { nt } & \text { F } \\ 2 & 2 & 0 & \text { NA } & \text { nt } & \text { F } \\ 29 & 12 & 10 & \text { NA } & \text { nt } & \text { F } \\ 41 & 2 & 18 & \text { NA } & \text { nt } & \text { C } \\ 7 & 2 & 1 & \text { NA } & \text { nt } & \text { F }\end{array}$




\begin{tabular}{|c|c|c|c|c|c|c|c|}
\hline No & 1 & 2 & 3 & 4 & 5 & 6 & 7 \\
\hline & Number of villages & 48 & 18 & 18 & & & \\
\hline & Area & Total & $\mathrm{CP}$ & LL & & & \\
\hline 155 & Rudbeckio-Solidaginetum & 51 & 8 & 27 & $\mathrm{X}$ & $\mathrm{O}$ & $\mathrm{C}$ \\
\hline 156 & Calystegio-Asteretum lanceolati & 1 & 1 & 0 & $\mathrm{X}$ & nt & $\mathrm{F}$ \\
\hline 157 & Impatienti glanduliferae-Calystegietum sepium & 8 & 4 & 0 & $\mathrm{X}$ & $\mathrm{O}$ & $\mathrm{F}$ \\
\hline 158 & Polygonetum cuspidati & 12 & 2 & 7 & $\mathrm{X}$ & $\mathrm{O}$ & $\mathrm{F}$ \\
\hline 159 & Sicyo-Echinocystietum lobatae & 1 & 1 & 0 & $\mathrm{X}$ & $\mathrm{O}$ & $\mathrm{F}$ \\
\hline 160 & Helianthetum decapetali & 13 & 3 & 4 & $\mathrm{X}$ & $\mathrm{O}$ & $\mathrm{F}$ \\
\hline 161 & Agropyro repentis-Aegopodietum podagrariae & 200 & 65 & 75 & NA & $\mathrm{nt}$ & $\mathrm{C}$ \\
\hline 162 & Aegopodio-Petasitetum hybridi & 16 & 5 & 4 & NA & nt & $\mathrm{F}$ \\
\hline 163 & Anthriscetum sylvestris & 115 & 48 & 40 & NA & nt & $\mathrm{C}$ \\
\hline 164 & Chaerophylletum aromatici & 3 & 3 & 0 & NA & I & $\mathrm{F}$ \\
\hline 165 & Chaerophylletum bulbosi & 40 & 0 & 21 & NA & $\mathrm{nt}$ & $\mathrm{F}$ \\
\hline 166 & Aegopodio-Heracleetum mantegazziani & 1 & 0 & 0 & $\mathrm{X}$ & $\mathrm{O}$ & $\mathrm{F}$ \\
\hline 167 & Aegopodio-Reynoutrietum sachalinensis & 2 & 0 & 0 & $\mathrm{X}$ & $\mathrm{O}$ & $\mathrm{R}$ \\
\hline 168 & Comm. Agropyron repens-Urtica dioica & 130 & 35 & 56 & NA & $\mathrm{nt}$ & $\mathrm{C}$ \\
\hline 169 & Alliario-Chaerophylletum temuli & 22 & 13 & 3 & NA & $\mathrm{nt}$ & $\mathrm{C}$ \\
\hline 170 & Myosotido sparsiflorae-Alliarietum petiolatae & 1 & 0 & 1 & NA & $\mathrm{nt}$ & $\mathrm{F}$ \\
\hline 171 & Geo urbani-Chelidonietum majoris & 87 & 4 & 43 & NA & $\mathrm{nt}$ & $\mathrm{F}$ \\
\hline 172 & Torilidetum japonicae & 6 & 1 & 4 & NA & I & $\mathrm{F}$ \\
\hline 173 & Galio aparines-Veronicetum sublobatae & 48 & 0 & 27 & NA & nt & $\mathrm{F}$ \\
\hline 174 & Impatientetum parviflorae & 18 & 3 & 12 & $\mathrm{X}$ & $\mathrm{O}$ & $\mathrm{C}$ \\
\hline 175 & Epilobio montani-Geranietum robertiani & 5 & 0 & 1 & NA & $\mathrm{V}$ & $\mathrm{F}$ \\
\hline 176 & Stachyo sylvaticae-Impatientetum noli-tangere & 1 & 0 & 1 & NA & $\mathrm{V}$ & $\mathrm{F}$ \\
\hline 177 & Onopordetum acanthii & 12 & 1 & 5 & SR & $\mathrm{V}$ & $\mathrm{F}$ \\
\hline 178 & Potentillo argenteae-Artemisietum absinthii & 24 & 4 & 6 & SR & nt & $\mathrm{F}$ \\
\hline 179 & Artemisio vulgaris-Echinopetum sphaerocephali & 2 & 1 & 1 & SR & I & $\mathrm{R}$ \\
\hline 180 & Berteroetum incanae & 12 & 1 & 5 & SR & nt & $\mathrm{C}$ \\
\hline 181 & Centaureo diffusae-Berteroetum incanae & 1 & 0 & 0 & SRS & I & $\mathrm{R}$ \\
\hline 182 & Artemisio campestris-Oenotheretum rubricaulis & 3 & 2 & 1 & SRS & nt & $\mathrm{F}$ \\
\hline 183 & Melilotetum albo-officinalis & 15 & 2 & 7 & SR & nt & $\mathrm{F}$ \\
\hline 184 & Poo compressae-Tussilaginetum & 10 & 4 & 4 & NA & nt & $\mathrm{F}$ \\
\hline 185 & Dauco-Picridetum hieracioidis & 29 & 1 & 19 & SR & nt & $\mathrm{F}$ \\
\hline 186 & Cerintho-Vicietum villosae & 25 & 1 & 13 & SR & $\mathrm{O}$ & $\mathrm{F}$ \\
\hline 187 & Tanaceto-Artemisietum & 72 & 35 & 21 & SR & nt & $\mathrm{C}$ \\
\hline 188 & Sedo acri-Poetum compressae & 4 & 1 & 2 & SRS & nt & $\mathrm{R}$ \\
\hline 189 & Convolvulo arvensis-Agropyretum repentis & 145 & 45 & 61 & SR & nt & $\mathrm{C}$ \\
\hline 190 & Lepidietum drabae & 3 & 0 & 1 & SRS & nt & $\mathrm{F}$ \\
\hline 191 & Falcario-Agropyretum & 12 & 0 & 7 & SR & nt & $\mathrm{F}$ \\
\hline 192 & Chondrillo-Agropyretum & 1 & 0 & 0 & SR & I & $\mathrm{R}$ \\
\hline 193 & Convolvulo-Brometum inermis & 39 & 14 & 14 & SR & $\mathrm{O}$ & $\mathrm{F}$ \\
\hline 194 & Elymo-Rubetum caesii & 52 & 4 & 24 & SR & nt & $\mathrm{C}$ \\
\hline 195 & Rubo caesii-Calamagrostietum epigeji & 40 & 7 & 24 & SR & $\mathrm{O}$ & $\mathrm{F}$ \\
\hline 196 & Comm. Lathyrus tuberosus & 1 & 0 & 0 & SR & nt & $\mathrm{F}$ \\
\hline 197 & Comm. Saponaria officinalis & 15 & 5 & 8 & SR & nt & $\mathrm{F}$ \\
\hline 198 & Arctietum lappae & 100 & 38 & 36 & SR & I & $\mathrm{C}$ \\
\hline 199 & Leonuro-Ballotetum nigrae & 93 & 1 & 58 & SR & I & $\mathrm{C}$ \\
\hline 200 & Urtico urentis-Chenopodietum boni-henrici & 7 & 2 & 2 & SR & $\mathrm{E}$ & $\mathrm{R}$ \\
\hline 201 & Rumicetum obtusifolii & 82 & 31 & 26 & SR & $\mathrm{V}$ & $\mathrm{F}$ \\
\hline 202 & Hyoscyamo nigri-Conietum maculati & 1 & 1 & 0 & SR & I & $\mathrm{F}$ \\
\hline 203 & Lactuco-Anthriscetum caucalidis & 10 & 0 & 6 & SR & $\mathrm{V}$ & $\mathrm{R}$ \\
\hline 204 & Lycietum halimifolii & 9 & 0 & 5 & SR & nt & $\mathrm{F}$ \\
\hline 205 & Comm. Armoracia rusticana & 10 & 5 & 2 & SR & I & $\mathrm{F}$ \\
\hline \multirow[t]{2}{*}{206} & Comm. Bromus carinatus & 62 & 13 & 25 & SR & $\mathrm{O}$ & $\mathrm{F}$ \\
\hline & Annual segetal and ruderal communities & & & & & & \\
\hline 207 & Spergulo arvensis-Scleranthetum аппиi & 11 & 7 & 2 & SS & $\mathrm{nt}$ & $\mathrm{C}$ \\
\hline 208 & Echinochloo-Setarietum pumilae & 8 & 2 & 4 & SS & $\mathrm{O}$ & $\mathrm{C}$ \\
\hline 209 & Spergulo-Echinochloetum cruris-galli & 20 & 1 & 12 & SS & I & $\mathrm{R}$ \\
\hline
\end{tabular}




\begin{tabular}{|c|c|c|c|c|c|c|c|}
\hline \multirow[t]{3}{*}{ No } & 1 & 2 & 3 & 4 & 5 & 6 & 7 \\
\hline & Number of villages & 48 & 18 & 18 & & & \\
\hline & Area & Total & $\mathrm{CP}$ & LL & & & \\
\hline 210 & Digitarietum ischaemi & 6 & 2 & 2 & SS & $\mathrm{nt}$ & $\mathrm{F}$ \\
\hline 211 & Setario-Lycopsietum arvensis & 11 & 7 & 4 & SS & $\mathrm{I}$ & $\mathrm{R}$ \\
\hline 212 & Spergulo-Chrysanthemetum segetum & 1 & 1 & 0 & SS & $\mathrm{V}$ & $\mathrm{R}$ \\
\hline 213 & Sclerantho-Arnoseridetum minimae & 7 & 3 & 1 & SS & $\mathrm{V}$ & $\mathrm{F}$ \\
\hline 214 & Papaveretum argemones & 53 & 15 & 24 & SS & $\mathrm{I}$ & $\mathrm{C}$ \\
\hline 215 & Vicietum tetraspermae & 14 & 3 & 10 & SS & $\mathrm{I}$ & $\mathrm{C}$ \\
\hline 216 & Aphano arvensis-Matricarietum chamomillae & 39 & 13 & 16 & SS & $\mathrm{V}$ & $\mathrm{F}$ \\
\hline 217 & Veronico agrestis-Fumarietum officinalis & 24 & 8 & 8 & SS & $\mathrm{V}$ & $\mathrm{F}$ \\
\hline 218 & Oxalido-Chenopodietum polyspermi & 9 & 5 & 1 & SS & $\mathrm{V}$ & $\mathrm{F}$ \\
\hline 219 & Euphorbio peplidis-Galinsogetum ciliatae & 77 & 15 & 37 & SS & $\mathrm{nt}$ & $\mathrm{C}$ \\
\hline 220 & Chenopodietum stricti & 44 & 17 & 14 & SR & $\mathrm{nt}$ & $\mathrm{C}$ \\
\hline 221 & Chenopodio-Descurainietum sophiae & 16 & 6 & 5 & SR & $\mathrm{I}$ & $\mathrm{F}$ \\
\hline 222 & Erigeronto-Lactucetum serriolae & 77 & 3 & 46 & SRS & $\mathrm{nt}$ & $\mathrm{F}$ \\
\hline 223 & Sisymbrio-Atriplicetum nitentis & 1 & 0 & 1 & SRS & $\mathrm{nt}$ & $\mathrm{F}$ \\
\hline 224 & Elymo repentis-Sisymbrietum loeselii & 6 & 1 & 2 & SRS & $\mathrm{O}$ & $\mathrm{C}$ \\
\hline 225 & Hordeetum murini & 63 & 0 & 42 & SRS & $\mathrm{O}$ & $\mathrm{F}$ \\
\hline 226 & Hyoscyamo nigri-Malvetum neglectae & 54 & 11 & 24 & SR & $\mathrm{nt}$ & $\mathrm{C}$ \\
\hline 227 & Matricario discoideae-Anthemidetum cotulae & 9 & 6 & 1 & SR & $\mathrm{E}$ & $\mathrm{R}$ \\
\hline 228 & Matricarietum discoideo-recutitae & 25 & 14 & 7 & SR & I & $\mathrm{R}$ \\
\hline 229 & Comm. Euphorbia peplus-Stellaria media & 30 & 2 & 15 & SR & $\mathrm{nt}$ & $\mathrm{F}$ \\
\hline 230 & Panico sanguinalis-Eragrostietum & 5 & 0 & 1 & SRS & $\mathrm{O}$ & $\mathrm{C}$ \\
\hline 231 & Erigeronto-Bryetum & 53 & 6 & 33 & SRS & $\mathrm{O}$ & $\mathrm{C}$ \\
\hline 232 & Linario vulgaris-Brometum tectorum & 7 & 2 & 3 & SRS & $\mathrm{nt}$ & $\mathrm{C}$ \\
\hline 233 & Conyzo-Senecionetum viscosi & 1 & 0 & 0 & SRS & $\mathrm{nt}$ & $\mathrm{RR}$ \\
\hline 234 & Poetum anпuae & 162 & 41 & 70 & NA & $\mathrm{nt}$ & $\mathrm{C}$ \\
\hline 235 & Matricario matricarioidis-Polygonetum arenastri & 134 & 37 & 55 & SRS & $\mathrm{nt}$ & $\mathrm{C}$ \\
\hline 236 & Poo-Coronopodetum squamati & 1 & 0 & 1 & SR & $\mathrm{E}$ & $\mathrm{R}$ \\
\hline 237 & Polygono arenastri-Lepidietum ruderalis & 10 & 1 & 8 & SRS & nt & $\mathrm{C}$ \\
\hline 238 & Chenopodio glauci-Puccinellietum & 2 & 0 & 2 & SRS & $\mathrm{O}$ & $\mathrm{F}$ \\
\hline 239 & Bryo argentei-Saginetum procumbentis & 59 & 8 & 25 & SR & $\mathrm{nt}$ & $\mathrm{C}$ \\
\hline 240 & Rumici acetosellae-Spergularietum rubrae & 9 & 1 & 5 & SR & $\mathrm{nt}$ & $\mathrm{F}$ \\
\hline 241 & Herniarietum glabrae & 4 & 1 & 0 & SR & $\mathrm{nt}$ & $\mathrm{F}$ \\
\hline 242 & Poo-Oxalidetum corniculatae & 5 & 0 & 2 & SRS & $\mathrm{nt}$ & $\mathrm{F}$ \\
\hline 243 & Polygonetum calcati & 3 & 1 & 2 & SRS & $\mathrm{O}$ & $\mathrm{F}$ \\
\hline
\end{tabular}

Explanations: $2^{*}$ - the number of occurrences in the complexes of all 48 studied villages, 3 - the number of occurrences in the complexes of 18 villages of central Pomerania (CP), 4 - the number of occurrences in the complexes of randomly selected 18 villages of Lubuskie Lakeland (LL), 5 - syngenesis (for explanation see text), 6 - category of dynamic tendencies under human impact in Poland - category of threat ( $\mathrm{E}$ - endangered, $\mathrm{V}$ - vulnerable, $\mathrm{I}$ - not determined, $\mathrm{nt}$ - not threatened communities, $\mathrm{O}$ - communities expanding their range), 7 frequency in Poland ( $\mathrm{RR}$ - extremely rare, $\mathrm{R}$ - rare, $\mathrm{F}$ - frequent, $\mathrm{C}$ - common)

* List of studied villages

in Pomerania (18): Chotkowo, Gardna Mała, Kluki, Królewo, Kwasowo, Łącko, Łąkie, Marszewo, Marwice (the only village situated beyond the area marked on the map), Nosalin, Noskowo, Radosław, Rzyszczewo, Sierżno, Staniewice, Ścięgnica, Tagowie and Wrząca;

in the Lubuskie Lakeland: (a) randomly selected 18 villages for comparison with the villages in Pomerania - Bielice, Chociszewo, Glińsk, Jemiołów, Jeziory, Lisów, Lubiechnia Wielka, Lubień, Lubin, Lubinicko, Lutol Suchy, Łagowiec, Mierczany, Radówek, Rogoziniec, Rusinów, Żelechów; (b) other villages (12): Koryta, Laski Lubuskie, Łagówek, Międzylesie, Niedźwiedź, Ojerzyce, Opalewo, Rzeczyca, Starków, Templewo, Wielowieś and Wolimirzyce. 